\title{
On Oidiopsis taurica (Lév.), an endophytic member of the Erysiphaceae ${ }^{1}$.
}

\author{
BY \\ ERNEST S. SALMON, F.L.S., \\ South-Eastern Agricultural College, Wye, Kent. \\ With Plates XIII and XIV.
}

$\mathrm{N}$ a preliminary note published (1) at the beginning of last year, I called 1 attention to the fact that Erysiphe taurica Lév. is endophytic in its conidial stage, the conidiophores being sent through the stomatal apertures into the open air from intercellular hyphae in the mesophyll of the leaf, instead of arising from a superficial mycelium on the surface of the leaf, as in all hitherto known species of the Erysiphaceae. Further, the conidiophore is frequently found to be branched, a character not previously known to occur in the Family.

During the past year I have examined a large number of specimens of E. taurica in the conidial and perithecial stages ${ }^{2}$, and I propose now to give the results of this examination, and also to make some observations on the life-history of E. taurica, and on the systematic position of the species. It may be mentioned here that one result of the examination of the collected material has been the establishment of the identity of several recently published fungi with $E$. taurica.

In the early stages of the conidial condition $E$. taurica in no way resembles the other species of the Erysiphaceae. This is due to two peculiarities, viz. the complete absence at this stage of any mycelium on the surface of the leaf, and the presence of conidiophores emerging singly or in bundles through the stomatal apertures (see Figs. 5-7, 12, 13, 17). The conidiophore is thin-walled, septate, flaccid, 200 to $700 \mu$, or more, in length, sometimes simple ${ }^{3}$, but more often branched. The branching is

1 From the Jodrell Laboratory, Royal Botanic Gardens, Kew.

2 All the material mentioned in the present paper is deposited in the Kew Herbarium.

${ }^{3}$ It is possible that the simple conidiophore becomes branched at a later stage through the production of lateral branches. In the example shown in Fig. 6 the lateral branches evidently arose at a late stage in the growth of the conidiophore, as shown by the fact that the walls of the main axis are comparatively thick, while the walls of the developing lateral branch are very thin (see $x, x)$. Compare also Fig. $\mathbf{1} 3$.

[Annals of Botany, Vo1. XX. No. LXXVIII. April, 1906.] 
sometimes monopodial (and repeated in the branches of the first and secord order) and more or less definite; at other.times it is apparently quite indefinite. From certain cases observed, it appears that mycelial hyphae may grow out from the conidiophore. The conidia are borne singly at the apices of the main axis and lateral branches. It appears, from certain dried examples which I have seen, that after the first conidium has been abstricted another may sometimes be produced ${ }^{1}$. In this character the present fungus resembles Phyllactinia (see (5), p. 494). The conidium is extremely variable in size and shape, even when taken from the same host-plant, as can be seen by referring to the figures in Plates XIII and XIV. On some hosts, however, the conidium shows constant and distinctive characters as regards its shape. The variations shown by the conidium in examples of the species on different host-plants will be dealt with fully below.

As mentioned above, the mycelium is at first wholly internal. The endophytic hyphae are abundant just below the epidermis, where they run freely in the intercellular spaces, and often form a kind of thin weft. Besides winding in and out among the intercellular spaces between the cells of the spongy parenchyma, the hyphae not infrequently extend to the intercellular spaces between the cells of the palisade tissue. In those cases where stomata are frequent on both surfaces of the leaves, the intercellular mycelium runs throughout the intercellular spaces of the mesophyll, and sends out the conidiophores and the hyphae of the external mycelium through the stomata of both surfaces to an equal extent. The hyphae of the endophytic mycelium are septate, from 4 to $6 \mu$ in diameter, and are sometimes tortuous and branched, with numerous free ends, while they sometimes run nearly straight for considerable distances in the intercellular spaces just below the epidermis (Fig. 3). Often mesophyll cells, here and there, become closely invested by a weft of hyphae. From the intercellular hyphae small haustoria, more or less globular in shape, are sent into the mesophyll cells, both those of the spongy parenchyma and frequently also those of the palisade tissue. I have not observed any, cases in which the epidermal cell has been entered for the production of a haustorium by penetration of the inner wall.

In the later stages of the conidial condition, the fungus becomes more evident on the surface of the host-plant, and approaches in habit the other members of the Erysiphaceae, because mycelial hyphae now emerge in

1 The statements of authors with regard to this point have been as follows. Sorokine (in Revue mycolog., I 889 , p. I46), speaking of Erysiphe Saxaouli [=E.taurica], says, 'Il n'y a qu'une seule spore sur chaque hyphe verticale.' Scalia writes of Oidiopsis sicula, 'conidiis catenulatis, facillime secedentibus,' and states that when the conidiophore is branched ' a chain of conidia, in the manner of Oidium, is produced on each branch.' The same author in his diagnosis of Oidium gigasporum says, 'conidiis catenulatis,' and also, 'the conidia become abstricted directly they are formed.' Maire observes, 'Les conidiophores donnent naissance à leur sommet à un petit nombre de conidies qui se forment et se désarticulent successivement; quelquefois il ne se forme qu'une seule conidie.' 
great numbers through the stomata, and form an external mycelium (varying in consistence from arachnoid to felted tomentose) on the surface of the leaf or stem preparatory to the formation of perithecia. In some cases it appears that some of the hyphae which form this external mycelium may arise as lateral branches from the conidiophores ${ }^{1}$. The hyphae of the external mycelium, in many cases if not in all, nourish themselves by sending down branches through the stomata, exactly as in the case of the hemi-endophytic mycelium of Phyllactinia (see Palla (11); also Monograph (2), p. 4, fig. 163). So far as I have been able to observe from the herbarium material available, no haustoria are sent by the external hyphae through the cuticle into the epidermal cells. Nevertheless the hyphae which creep on the surface of the leaf during the latter part of the conidial stage, and throughout the perithecial stage, possess peculiarly shaped short lateral branches, which in some cases are very similar to the appressoria on the hyphae of ectoparasitic species. These short lateral branches, which are figured in Plate XIII, Figs. 4, 20, 2I, are often closely applied to the surface of the epidermis, and appear to serve the purpose of attaching the hyphae to the leaf; in the herbarium material available I have not been able to observe that haustoria are ever produced from these appressoria. It may be noted here, as a fact of considerable interest, that the mycelial hyphae of the hemi-endophytic species Phyllactinia corylea possess appressoria of exactly similar shape, and in this species also no haustoria are sent into the epidermal cells from these organs.

I have been able to observe the early stages of germination of the conidium. Living examples of the fungus, in the conidial stage only, occurring on Ballota rupestris ${ }^{2}$, were kindly sent to me from Sicily by Prof. G. Scalia. As, unfortunately, plants of B. mpestris were not available for inoculation experiments, I used the leaves of Eryngium campestre, one of the host-plants of $E$. taurica. The leaves which were inoculated were treated as follows: At the place of inoculation the upper epidermis and most of the underlying mesophyll tissue were cut away, leaving the under epidermis intact. Conidia were sown on the cuticular surface of the uninjured epidermal cells over the wound, and the leaf placed, with the cut surface downwards, on damp blotting-paper at the bottom of a closed Petri dish. The stages of germination reached by the conidia are shown in Fig. 10. It is an interesting fact that the conidium on germination at once forms an appressorium, just as is the case with the germinating conidia of the ecto-

1 This accords with the observations made by Maire (6) in his paper referred to later. This anthor remarks, writing of the superficial mycelium: 'Il est formé de tubes beaucoup plus fins que le mycélium interne. Ces tubes prennent naissance par ramification latérale des conidiophores près de leur base, ou plus haut, ou encore aux dépens de filaments spéciaux, sortant des stomates en même temps que les conidiophores.'

2 This is the form which has been described as Oidium gigasporum (see below, p. 190). 
parasitic species ${ }^{1}$. No formation of a haustorium from this appressorium was observed, nor was the germ-tube seen to enter a stoma; as, however, these conidia had been sown on an injured leaf of a strange host-plant as regards the form of the fungus used, these negative results are of little importance.

The identity of four recently published species with E. taurica may here be pointed out.

In 1900 Magnus published (7), as a new species, Oidium Haploplyylli, occurring on Ruta (Haplophyllum) Buxbaumii, in Palestine. Through the kindness of Prof. P. Magnus I have been able to examine the type specimens of this fungus, and have found the endophytic mycelium, the branched conidiophores emerging through the stomata of the leaf, and the large, curiously shaped conidia characteristic of E. taurica.

In I902 Scalia described (9), (10), as a new genus of the Hyphomycetes, a fungus occurring on Asclepias curassavica in Sicily. A careful and very interesting description of the fungus, to which the author gave the name of Oidiopsis sicula, was published (1.c.), and I give below (in translation) the more important biological observations there recorded: "The fungus forms on the upper surface of the leaves purple spots, which are more or less extended and always limited by the midrib and its branches. Corresponding to these spots, one observes on the lower surface a kind of white mealy tomentum, which at first sight makes one doubt whether one is not dealing with a Peronospora. The injury caused is entirely comparable to that brought about by species of Peronospora. The leaf dries up very quickly, either locally at the isolated spots, or the whole lamina withers if the spots become confluent, so as to cover its surface. The plants become rather easily defoliated, and flower badly. In gardens in Sicily the fungus lives all the year on $A$.curassavica; in the summer months the spots are not observable on the upper surface of the leaf. Plants cultivated in damp and shady localities are injured most. The maximum of infection takes place during the winter, and chiefly if the season is mild. The fungus develops less actively during the summer months; unless there are prolonged rains, or even simply damp winds.'

At the same time Scalia published $(10$, p. 9) a fungus occurring on Ballota mpestris, in Sicily, as a new species of Oidium, under the name of Oidium gigasporum. In the description the following characters are given: "The fungus appears as coloured spots on the upper surface of the leaves, on the lower surface and corresponding to these spots one observes a white mealy pruinose layer, somewhat clearly visible among the hairs with which the leaf is abundantly provided. The mycelium is composed of creeping hyphae which are branched and hyaline, and form

1 The figure to the right represents a conidium twenty-four hours after being sown; that to the left, after forty-eight hours. 'On the sixth day the germ-tube was considerably longer, and passing several stomata (which, however, were not functional) had developed two more 'appressoria.' 
a rather delicate arachnoid weft. From the sterile hyphae arise the conidiophores, which are for the most part simple, though sometimes at their base a secondary branch is developed. The conidia, formed at the apex of these conidiophores, become abstricted directly they are formed. Of these conidia, the terminal one is usually attenuated at the apex and truncate at the base, while the others are cylindrical and rounded at both ends, and roughly oval. This species is absolutely distinct from the other species of the genus [Oidium] in the much greater dimensions of the conidia, as well as in the host-plant on which it lives; it is, however, very like the following species [Oidiopsis sicula] in almost all its characters, although the mycelium in the present species is superficial, as in typical species of Oidium, while in Oidiopsis sicula it is endophytic.'

Through the courtesy of Prof. G. Scalia I have been able to examine excellent dried examples of Oidiopsis sicula and Oidium gigasporum, and also spirit material of the former. There is no doubt that both belong to E. taurica, Lév., and represent the conidial condition of the species in the earlier and later stages. In the specimens collected of Oidiopsis sicula on Asclepias curassavica which I have seen, no external mycelium is yet visible, while in those of Oidium gigasporum on Ballota rupestris mycelial hyphae are evident on the surface of the leaf. Representations of the fungus on Asclepias are given in Figs. 5-7 and 29. On Ballota rupestris the conidiophores are very laxly branched, and very flaccid, and their origin from the endophytic mycelium is difficult to trace on account of the dense coating of hairs completely covering the under surface of the leaf. I have observed clearly, however, that the fungus sends hyphae into the stomata (see Fig. 18). I have lately received from Prof. F. Bubák examples (unnamed) of the same form collected in Montenegro on Ballota acuta $(=B$. rupestris $)$, and in these specimens young perithecia of E. taurica are visible on the external mycelium among the conidiophores.

Magnus has recently published (8) a fungus, growing on Asteriscus aquaticus (= Odontospermum aquaticum) at Santa Cruz, Teneriffe, as a new species under the name of Erysiphe Asterisci ${ }^{1}$. I have seen the examples sent out in Rabenh.-Pazschke, Fungi europ. et extraeurop., ed. nov., ser. 2, nr. $435^{\circ}$, and after a careful examination have failed to find any distinguishing characters from E. taurica. The perithecia, which are semi-immersed in the persistent felted mycelium, measure $200-240 \mu$ in diameter, and when dry become strongly concave or 'pezizoid' in the manner characteristic of $E$. taurica; the asci are numerous, and large, and contain two ascospores more or less immature. In all respects, in fact, E. Asterisci is typical $E$. taurica as regards the perithecial characters; and it is somewhat curious that Magnus in his diagnosis should have omitted to have compared the fungus with this species (especially as Odontospermum had been recorded as

1 The name (without diagnosis) appears in Engl. Bot. Jahrb. xxxiii, 486 (1903). 
a host-plant of E. taurica) whilst mentioning ' E. Linkii, Lév.' and E. Cichoracearum DC. Magnus makes the following observations with regard to the conidial stage: 'Die Art ist schon durch ihre Konidien sehr ausgezeichnet. Die Konidien sind ausserordentlich lang gestreckt. Sie sind durchschnittlich $52,5 \mu$ lang und $16,5 \mu$ breit. Ihre Oberfläche ist körnig rauh. Sie werden dicht an der Basis von den Konidienträgern schon abgeschnürt. Wohl in Zusammenhang mit ihrer bedeutenden Länge traf ich sie niemals kettenförmig am Konidienträger, sondern immer nur einzeln an dẹmselben.' It may be mentioned here that already in I900 (2, p. 22x) I had pointed out that the conidia of $E$. taurica were remarkable for their large size, frequently measuring $50 \times 18 \mu$. The conidia which occur in the examples of $E$. Asterisci in Rabenh.-Pazsch., nr. 4350, in the Kew Herbarium, measure $40-65 \times I_{5}-20 \mu$, and show the characteristic shape for E. taurica (see Fig. 37). I have no hesitation in sinking E. Asterisci to a synonym of $E$. taurica.

I have ascertained the presence of endophytic mycelium, sending out hyphae and branched conidiophores through the stomata, in dried examples of $E$. taurica in the perithecial stage on the following hostplants: Clematis songarica, Peganum Harmala, Centaurea dissecta subsp. Parlatoris, Verbascum Blattaria, V.phlomoides, V. Lychnitis, V. bithynicum, $V$. Thapsus, Althaea kurdica, Euphorbia lanata, Carlina lanata, Helianthemum oelandicum, Psoralea drupacea, P. bituminosa, Acanthophyllum glandulosum, Hedysarum Falconeri, Artemisia Dracunculus, Odontospermum aquaticum, Daucus maximus, Nepeta podostachys, Astragalus sp., Zygophyllum Fabago, Vicia temifolia, Passerina annua, Teucrium Chamaedrys, Chondrilla juncea, Chrozophora tinctoria, Capparis spinosa, Cousinia concinna, Foeniculum vulgare, Phlomis Herba-venti, Marrubium peregrinum, Cynara Cardunculus, Scutellaria multicaulis, Cleone arabica, Ballota rupestris, Epilobium hirsuium. I have seen examples in the conidial stage only on Onobrychis viciaefolia, Asclepias curassavica, Cistus monspeliensis, Ruta Buxbaumii, and Mimulus glutinosus.

In my 'Preliminary Note' (1) I pointed out that E. taurica, on account of its possession of certain anomalous features described above, viz. the endoparasitic mode of life and the morphological peculiarities of the conidiophores, would probably require to be separated as a distinct genus. In a paper appearing soon afterwards (6), Maire reported that he had discovered an endophytic mycelium in an example of $E$. Cichoracearum DC. on Cirsium eriophorum. The example in question, which is contained in Montagne's herbarium in the Paris Museum, was referred to $E$. taurica by Léveillé. The fungus clearly belongs, however, to $E$. Cichoracearum, as here pointed out by Maire, and previously by me in I900 in my monograph. I have been able to re-examine this fungus, and have seen the original examples from Montagne's herbarium, and also a fragment of the same 
specimen used by Maire in his examination. I was able to ascertain that in these specimens the conidiophores arise from superficial hyphae of the mycelium, and that these hyphae send haustoria into the epidermal cells. I was not able to observe any endophytic mycelium in the specimens I examined. In face of the presence of the normal Oidium-type of conidiophore borne by ectoparasitic hyphae, I see no reason to doubt that this fungus on Cirsium is E. Cichoracearum, and I suspect that the endophytic hyphae (which Prof. Maire tells me in a letter he observed in two or three instances) belonged to some other parasitic fungus.

I am still of the opinion that E. taurica is distinct generically from the other members of the Erysiphaceae in its completely endophytic habit during the early part of its conidial stage, and in the production of usually branched conidiophores sent up through the stomata. I propose to establish for the reception of this genus, which must bear the name Oidiopsis, a new Sub-family, Oidiopsideae, with the following characters :Mycelium at first wholly endophytic, producing conidiophores sent up through the stomata; perithecia produced on the hyphae of a superficial mycelium originating from the endophytic mycelium.

The generic characters of Oidiopsis as defined by Scalia will require to be considerably extended. Scalia described his genus from the single example of the fungus in the conidial condition on Asclepias curassavica, at a stage when no superficial mycelium occurred. We have then to add to the characters given the presence of the hemi-endophytic mycelium on the surface of the leaf (during the later stage of the conidial condition, and throughout the perithecial stage), originating from hyphae sent up through the stomata, and the generic perithecial characters proper to the fungus in its perithecial stage, viz., those of the fungus hitherto known as Erysiphe taurica Lév. The genus, then, will stand as Oidiopsis Scalia (emend.), and the species as $O$. taurica (Lév.).

The Family Erysiphaceae will consist of three Sub-families: I. Erysipheae, in which the mycelium is wholly external to the tissues of the host-plant, the hyphae sending haustoria into the epidermal cells alone, or, in one species (Uncinula Salicis (DC.) Wint.), into the sub-epidermal cells as well ${ }^{1}$. Genera: Podosphaera, Sphaerotheca, Uncimula, Microsphaera, Erysiphe. 2. Phyllactinieae, in which the conidiophore and perithecium are borne on superficial mycelium, which does not form haustoria in the epidermal cells, but sends down through the stomata special branches, of limited growth, which send haustoria into cells of the mesophyll-tissue. I genus, Phyllactinia. 3. Oidiopsideae, with the characters given above. I genus, Oidiopsis.

Thus within the Family Erysiphaceae we pass from ectoparasitism, through a hemi-endophytic form, to endoparasitism. 
The discovery of the existence of an endophytic member of the Erysiphaceae leads us naturally to ask the question whether the fact will have any bearing on the subject of the phylogeny of the group. If we find reason to believe that the endophytism is a primitive character, then we may seek relationship for the conidial stage of $O$. taurica with the genera Ovularia and Ramularia. In species of these two genera, the conidiophores emerge through the stomata in bundles from an endophytic mycelium just as in Oidiopsis; we find, too, in certain species of Ovularia and Ramularia a vague branching of the conidiophore and laterally borne conidia (cf. Fig. 2). On certain of its host-plants (e.g. on Asclepias) $O$. taurica causes, as a result of its parasitism, discoloured spots on the surface of the leaf which are limited by the midrib and its branches; the same habit, it may be noted, is found in species of Ovularia and Ramularia. On the other hand, we may find reason to believe that the endophytism of $O$. taurica is not a primitive character, but one acquired by the species to meet certain special conditions, and that it bears no phylogenetic significance. Valuable evidence bearing on the point will probably be obtained when the entire process of the germination of the conidium and ascospore of $O$. taurica, and the first establishment of the endophytic mycelium, have been thoroughly investigated.

Some remarks may here be made on the distribution and habitats of O. taurica. From the recorded distribution the species is seen to be a lover of warm or dry localities, being found most commonly in the hot dry countries of Central Asia, such as Turkestan, Persia, India, Syria, and Turkey. The species occurs also frequently in South Russia and the Crimea, Bulgaria, Greece, Italy, and Sicily, and has been likewise found in France, Spain, Germany, Hungary, and Algeria. The occurrence of the species in America (California) is noted below. The distribution of the plant shows on the whole that the species is peculiarly fitted to exist under xerophytic conditions. In Turkestan (Seravschan), at a height of 6,000 feet, $O$. taurica is found abundantly-occurring up to $4-5,000$ feet on almost all the plants of the steppes. The species is reported as being abundant, also, about the central part of Karakoum, Central Asia. In India it has been collected between Lama Yara and the Phatu Pass, where it must be exposed to very dry winds. Indian specimens, collected by Mr. J. F. Duthie, were found growing on Hedysarum Falconeri under practically desert conditions. Examples (now in the Kew Herbarium) growing on Zygophyllum Fabago were collected by Dr. O. Stapf at Ispahan, in Persia, where a xerophytic desert or desert-steppe type of flora exists. The species occurs also commonly on plants growing in the deserts of Syria, Kurdistan, Palestine, \&c.

It seems very possible that $O$. taurica, by acquiring or retaining the endophytic mode of life, has been enabled to grow in dry, hot countries, the 
endophytism serving to meet the need of the fungus to shelter its mycelium in the early stages of the conidial condition from dry burning winds or hot sun, or being due to the inability of the fungus to pierce the thick cuticle of xerophytic plants for the formation of haustoria, and the consequent need to enter the plant in order to obtain nourishment ${ }^{1}$. It must be noted, however, that in a few cases $O$. taurica is found on leaves possessing a cuticle which other members of the Erysiphaceae are able to pierce, thus both $O$. taurica and E. Cichoracearum are found on Verbascum Lychnitis and $V$. phlomoides.

The fact of the occurrence of an endophytic member of the Erysiphaceae must be remembered in future when discussing the significance of the case of induced endophytism under cultural conditions of a normally ectoparasitic species (Erysiphe Graminis DC.) which I have lately reported (4).

A very interesting fact is the possession by Oidiopsis and Phyllactinia of certain well-marked characters common to both. We find in these two genera the following characters marking them off from the other genera of the Erysiphaceae :- a hemi-endophytic superficial mycelium ; lateral appressoria-like organs on the superficial mycelial hyphae; conidia distinguished by their large size ${ }^{2}$, the nature of the epispore, and variability in size and shape; and finally, as is noted below (p. 197), the production on certain hosts of a well-marked variety showing constant and distinctive morphological characters which are very similar in both species.

These points of resemblance would seem to show either that Oidiopsis and Phyllactinia are related phylogenetically, or that they have each been modified in the same direction under more or less similar conditions.

We will now consider the variation in shape and size which is shown by the conidia. As can be seen by reference to Plate XIV, the conidium is sometimes cylindrical with rounded ends, $50-80 \times 12-20 \mu$; more often it is ovoid, oblong, or subcylindric, often distinctly narrowed and more or less sub-acuminate towards the apex, $35^{-82} \times 13^{-2} 3 \mu$; or it may be broadly oblong, and rounded at both ends, $38-60 \times 20-28 \mu$. Very rarely the conidium is quite small, oblong and rounded, truncate at both ends, and measuring only $22-32 \times 13^{-16} \mu$. It is very probable that the great differences in shape and size shown by the conidium, even on the same host-plant, may to a certain extent be correlated with the position of the conidium on the conidiophore. The first conidium produced on the main axis differs probably from those subsequently produced, and both of these

1 Maire (6) remarks: 'Le mycelium endophytique n'est qu'une adaptation à un hôte xérophyte et à un climat sec.'

${ }^{2}$ The large size of the conidium is perhaps due to the need of the germ-tube to be provided with sufficient food-material to enable it to grow on the surface of the leaf until it finds a suitable stoma to enter. Very probably the germ-tube requires to form one or several appressoria before it enters the stoma. 
again may differ in size if not in shape from the conidia produced on the branches of the first and second order ${ }^{1}$.

Maire describes (6) the conidium as follows: 'conidiis cylindraceis vel oblongo-cylindraceis, vel ovoideo-oblongis, utrinque retusis, vel apice attenuatis, $50-70 \times 15^{-1} 8 \mu$ '. Two varieties are then founded by this author with the following characters: "var. Duriaei (Lév.) A typo differt conidiis minoribus, $38-45 \times 14-18 \mu$ ', on Phlomis Herba-venti and $P$. pungens; and 'var. Zygophylli R. Maire. A typo differt conidiis longe cylindraceis, 57$72 \times 13^{-14} \mu$ ', on Zygophyllum Fabago.

An examination of a large number of examples of the conidial stage of $O$. taurica, on thirty-seven species of its host-plants, has convinced me that we cannot separate satisfactorily varieties on the characters here given.

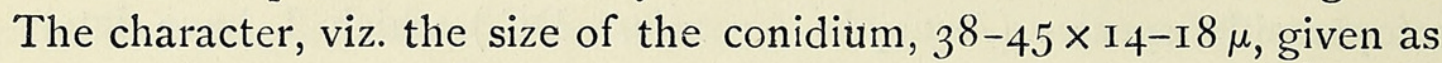
distinctive of the 'var. Duriaei', does not hold good. In an authentic specimen of ' $E$. Duriaei Lév.', from Léveillé's herbarium, at Kew, the conidia measure $43-60 \times 18-23 \mu$ (Fig. 24). This example occurs on Phlomis $H e r b a-v e n t i$. In the example on $P$. pungens sent to me by Prof. Maire as ' $E$. taurica var. Duriaci' the largest conidia measure $50 \times 20 \mu$; mixed with these are remarkably small ones-the smallest I have seen-measuring only 22 $32 \times 13-16 \mu$ (Fig. 22). Conidia as small as $28 \times 13 \mu$ occur mixed with conidia measuring $60 \times 25 \mu$ on Verbascum Thapsus (Fig. 23) and V. Lychnitis; on Euphorbia lanata (Fig. $3^{8}$ ) the conidia range from $35-55 \times 14-25 \mu$, and on Cynara Cardunculus from $35-50 \times 15-20 \mu$. Similar cases are quite common.

The characters put forward as distinctive of the 'var. Zygophylli' are even less satisfactory. In the example sent to me by Prof. Maire the conidia measure $60-73 \times 13-20 \mu$; their shape is shown in Fig. 22**. In an example on the same host-plant, collected by Dr. O. Stapf in Persia, the conidia vary from $45^{-60} \times \mathrm{I}_{4}-18 \mu$, and often depart from the cylindrical shape (Fig. 27). Cylindrical conidia measuring $85 \times 16 \mu$ occur intermixed with oblong-elliptic conidia measuring $44 \times 22 \mu$, on Ruta Buxbaumii (Fig. 28). Exactly similar cases are found in the forms of the fungus on Asclepias curassavica (Fig. 29), Nepeta podostachys (Fig. 34), Capparis herbacea, Psoralea bituminosa, and Passerina annua (Fig. $3^{6}$ ).

On certain host-plants, however, we do find a well-marked, constant, and distinctive variation in the shape of the conidium. I first met with this in an example, in the conidial stage only, sent to me by Prof. L. M. Underwood, from the Herbarium of the Columbia University, labelled

1 Scalia says of Oidium gigasporum, 'Conidiis catenulatis cylindraceis vel fere ovalibus, apicali sursum acutato, caeteris utrinque truncatulis,' and 'the terminal conidium is usually attenuated at the apex, and truncate at the base, while the others are cylindrical and rounded at both ends and roughly oval.' The same author writes of Oidiopsis sicula, 'conidiis catenulatis, conidio apicali sursum longe papillato, basi truncato, rotundato, caeteris cylindraceis, utrinque rotundatotruncatulis.' 
' Oidium obductum, Ell. \& Lang. f. Mimuli, E. \& E., on Mimulus glutinosus. Berkeley, California. (W. C. Blasdale.)' On examination, this was found to be the conidial stage of a fungus possessing endophytic mycelium and branched conidiophores emerging through the stomata of the leaf (Figs. II-I3). In these characters it resembled $O$. taurica in its conidial stage, but the conidia of this fungus on Mimulus differed at first sight in being thick, uniformly oblong or cylindrical, and usually more or less angular in outline. This difference in the shape of the conidium, together with the fact that $O$. taurica has not hitherto been reported from America ${ }^{1}$, inclined me at first to the belief that the fungus might prove to be a new species of Oidiopsis, endemic to America, and distinct from the Old World species. On examining, however, further material of $O$. taurica on its numerous hosts in Europe and Africa, I discovered conidia of the same type in three cases, viz. on Daucus maximus from Greece, on Chondrilla juncea from Hungary, and on Foeniculum vulgare from Algeria. As in these cases perithecia are present, it seems clear that the American plant belongs to $O$.taurica. The plant on Daucus maximus was published as a new species under the name of Erysiphe lamuginosa by Fuckel in I87 I, the specific characters relied upon being certain mycelial and perithecial ones which proved, however, not to be distinctive (see 2, p. 21 8). In the diagnosis given, the conidial stage is thus described: 'Fungo conidiophoro dense lanuginoso-tomentoso, candido, late effuso, caules foliaque tota occupante, conidiis oblongo-ovatis, utrinque obtusis, hyalinis, 32 mik. long., I 6 mik.crass.'

I consider the distinctive shape shown constantly by the conidium in all the examples examined on these four host-plants (Mimulus glutinosus, Dancus maximus, Chondrilla juncea, and Foeniculum vulgare) of sufficient value for the separation of the plant as a variety, and I propose to use the name of lanuginosa (Fckl.) in giving the present form varietal rank.

The occurrence of $O$.taurica, in the conidial stage only, in a single locality in North America is a very surprising fact ; it seems, too, somewhat unlikely-considering the careful attention that has been paid to the Family by numerous mycologists in the United States-that the perithecial stage occurs frequently, if at all.

I should like here to draw attention to the curious case of parallel variation shown by $O$. taurica and Phyllactinia corylea. As I have lately pointed out (5), we find a marked variety of $P$. corylea, distinguished by the shape of the conidium, on certain of its host-plants. Now the shape of the

1 It may be pointed out here that the fungus occurring on Euphorbia sp., in the Argentine Republic, lately published by Spegazzini (14) as E. taurica Lév., var. andina, does not belong to E. taurica. As recorded in my Supplementary Notes (3, p. 191), this fungus on Euphorbia, while much recalling E. taurica in habit, and in the large size of some of the perithecia and their asci, clearly belongs to $E$. Cichoracearum DC. I have lately re-examined the authentic example in the Kew Herbarium, and can state that it shows the ectoparasitic mycelium and the conidial (Oidium) stage characteristic of E. Cichoracearum. 
conidium in this variety, which I have called angulata, is very closely similar to that found in the variety lanuginosa of $O$. taurica, as may be seen by comparing Figs. II-1 5, 30-33 in Pl. XIII, XIV with those given in my recent paper on Phyllactinia (5, Pl. XIV). Moreover, there is a similarity shown by the two varieties in their distribution and promiscuous choice of hosts, - P. corylea, var. angulata, being found in the United States on Quercus, Castanea, Fagus, and Ulmus, in South America on Adesmia, and in Europe on Hippophä̈; and O. taurica, var. lanuginosa, being found in the United States on Mimulus, in Europe on Daucus and Chondrilla, and in Africa on Foeniculum. Further, as pointed out above (p. 195), the two genera have several other common characters.

The conidium of $O$. taurica may be quite smooth or (especially when old) rough with protuberances due to the breaking-up of the epispore; in some cases-as, e.g., in specimens on Phlomis pungens, Odontospermum aquaticum, Vicia angustifolia, Clematis songarica, Cistus monspeliensis, Astragalus sp.-the epispore breaks up almost completely into flakes.

$O$. taurica is sometimes attacked in its conidial stage by the parasitic fungus Ampelomyces quisqualis - a fact which Prof. G. Scalia has independently observed. This parasite, whose life-history was first worked out by De Bary (12), causes a transformation of the conidium, or cell of the conidiophore, attacked, which turns a dark brown (see Fig. 8).

The synonymy of the present species, and its distribution and hostplants-additional to that given in my Monograph (2) and 'Supplementary Notes' (3)-are as follows :-

Oidiopsis taurica (Lév.).

Oidium Haplophylli P. Magn., in Verh. k. k. zool.-bot. Gesell. Wien, l., 445 (1900).

O. gigasporum Scalia, in Rendiconti del Congresso bot. Palermo, 9 (1 go2).

Oidiopsis sicula Scalia, in Rendiconti del Congresso bot. Palermo, Io (I902); Scalia, in L'Agric. Calabro-Siculo, xxvii, 396 (1902).

Erysiphe Asterisci P. Magn., in Hedwigia, xliv, I6, Taf. II (1904).

E. taurica Lév., var. Duriaei (Lév.), R. Maire, in Bull. Soc. Sci. Nancy, sér. 3, tom. vi, 6 (1905).

E. taurica Lév., var. Zygophylli, R. Maire, l.c., pl. ii (1905).

Distrib.-Add Europe: Sicily, Corsica, Montenegro; Africa : Canary Islands, Teneriffe, Santa Cruz.

Hosts.-Add: Asclepias curassavica (conidial stage only), Ballota rupestris, Centaurea dissecta subsp. Parlatoris, Cistus monspeliensis (conidial stage only), Cousinia concinna, Chrozophora tinctoria, Epilobium hirsutum, Onobrychis viciaefolia (conidial stage only), Psoralea bituminosa, Ruta Buxbaumii (conidial stage only), Verbascum bithynicum, V. Thapsus.

var. lanuginosa (Fckl.)

Erysiphe lanuginosa Fckl., in Bot. Zeit., 27 (1871). 
E. lichenoides, Trab. and Sacc., in Sacc., Syll. Fung., xi, 253 (1895).

A typo differt conidio crasso oblongo vel cylindrico plerumque ambilu plus minusve angulari, interdum medio constricto, $35^{-70} \times$ I 4-28 $\mu$.

Distrib.-Europe: Greece, Kephyssos, in Attica (de Heldreich, 1869 and $\mathbf{1} 87 \mathbf{r}$ ); Hungary, Ménes (Simonkai). Africa: Algeria, Ben Chicao, near Medea (Trabut). N. America: U. S. A., Berkeley, California (W. C. Blasdale).

Hosts.-Chondrilla juncea, Daucus maximus, Foeniculum vulgare, Mimulus glutinosus (conidial stage only).

Exsicc.-Rabenh. Fung. europ. nr. I520 (as $E$. lanuginosa); C. Roumeg. Fung. select. exsicc. nr. $60 \mathrm{I} 7$ (as $E$. lichenoides).

In conclusion, I wish to offer my sincere thanks to the following botanists who have kindly placed valuable material at my service: Professor C. E. Bessey, Professor F. Bubák, M. P. Hariot, Professor P. Magnus, Professor R. Maire, Professor G. Scalia, Dr. H. Sydow, and Professor L. M. Underwood.

\section{BIBLIOGRAPHY.}

1. Salmon, E. S.: Preliminary Note on an Endophytic Species of the Erysiphaceae. Ann. mycolog., iii, 82, 83 (1905).

2. - : A monograph of the Erysiphaceae. Mem. Torr. Bot. Club, ix (I900).

3. : Supplementary Notes on the Erysiphaceae. Bull. Torr. Bot. Club, xxix, 197 (1902).

4. conditions. Phil. Trans., cxcviii, 87 (1905).

5. Karst.-I. Ann. mycolog., iii, 493 (I905).

6. Maire, R. : Remarques sur quelques Érysiphacées. Bull. Soc. Sci. Nancy, sér. 3, t. vi, $3{ }^{I-37}$, pl. ii (I905).

7. Magnus, P.: J. Bornmüller, Iter Syriacum, I897. Verh. k. k. zool.-bot. Gesell. Wien, 1, 444 (I900).

8. (1904).

9. Scalia, G. : Di una nuova malattia dell' Asclepias curassavica Spr. L'Agric. Calabro-Siculo xxvii, 393-7 (1902).

10. - Micromycetes aliquot Siculi novi. Rendiconti del Congresso bot. Palermo, 9-I I (1902).

11. Palla, E.: Über die Gattung Phyllactinia. Berichte Deutsch. Botan. Gesell., xvii, 64-72, pl. 5 (I899).

12. De Bary, H. A. : Beitr. zur Morphol. und Physiol. der Pilze, I, §§ xiii, xiv. Abhandl. d. Senckenb. Naturf.-Gesell., vii (I 87 I).

13. Smith, Grant : The Haustoria of the Erysipheae. Bot. Gaz., xxix, I53-184, pl. II, I 2 (I900).

14. SpegazZin I, C. : Mycetes Argentinenses. Anal. Mus. Nac. Buenos Aires, viii, ser $3^{a}, 68$ (1902). 


\title{
EXPLANATION OF PLATES XIII AND XIV.
}

\author{
Illustrating Mr. Salmon's paper on Oidiopsis taurica.
}

Fig. I. Part of a branched conidiophore, from an example on Verbascum phlomoides.

Fig. 2. Conidiophores and conidia of Ovularia obliqua (Cooke), Oud., on Rumex obtusifolius.

Fig. 3. Portions of the endophytic intercellular mycelium, growing in the mesophyll of a leaf of Clematis songarica.

Fig. 4. Appressorial organs on hyphae of the superficial mycelium; to right, from an example on Helianthemum oelandicum ; to left, from an example on Verbascum phlomoides.

Figs. 5, 6, 7. Young conidiophores emerging through a stoma; the subsequent production of a lateral branch is shown at $x$. From an example on Asclepias curassavica. (= Oidiopsis sicula, Scalia.)

Fig. 8. Apical portion of two branched conidiophores, both attacked by Ampelomyces quisqualis. In one case the apical young conidium has been transformed; in the other, the penultimate cell. Lateral branches have begun to be produced from the conidiophore. From an example on Verbascum phlomoides.

Fig. 9. Apical portion of a conidiophore, showing the production of a lateral branch. From an example on Ballota rupestris (= Oidium gigasporum, Scalia).

Fig. Io. Conidia germinating on a leaf of Eryngium campestre (see p. 189).

Figs. II, I 2. Apical portion of a conidiophore and basal portion of another, from an example of the var. lanuginosa on Mimulus glutinosus.

Fig. I3. A simple conidiophore from the same example, showing the beginning of a lateral branch near the base.

Figs. I4, I5. Apical portions of two branched conidiophores from the same example.

Fig. 16. A branched conidiophore from an example on Verbascum.

Fig. 17. Hyphae emerging through a stoma (of the stem); one, to right, forming a conidiophore; one, to left, bearing a young perithecium. From an example on Passerina annua.

Fig. I8. Hypha of the superficial mycelium sending a branch through a stoma into the interior of the leaf. From an example on Ballota rupestris (= Oidium gigasporum, Scalia).

Fig. 19. Apical part of a much-branched conidiophore. From an example on Ruta (Haplophyllum) Buxbaumii (= Oidium Haplophylli, P. Magn.).

Fig. 20. Appressorial organs on hyphae of the superficial mycelium, from an example on Zygophyllum Fabago.

Fig. 2I. Ditto; from an example on Ballota rupestris (= Oidium gigasporum, Scalia).

Fig. 22. Conidia of O. taurica on Phlomis pungens.

Fig. $22 *$, ,

Fig. $22^{* *}$. ",

Fig. 23. "

Fig. 24. "

Fig. 25 .

Fig. 26.

Fig. 27 .

Fig. 28 .

Fig. 29.

Fig. 30 .

Fig. 3I.

Fig. $3^{2}$.

Fig. 33.

Fig. 34 .

Fig. 35 .

Fig. $3^{6}$.

Fig. $3 \%$

Fig. 38 .

Fig. 39 .
Cistus monspeliensis.

Zygophyllum Fabago.

Verbascum Thapsus.

Phlomis Herba-venti.

Verbascum Blattaria.

Peganum Harmala.

Zygophyllum Fabago.

Ruta Buxbaumii.

Asclepias curassavica.

O. taurica, var. lanuginosa, on Mimulus glutinosus.

$\begin{array}{lcc}", & \text { Chondrilla juncea. } \\ " & \text { Daucus maximus. } \\ " \text { taurica on Nepeta podostachys. }\end{array}$

O. taurica on Nepeta podostachys.

" Psoralea drupacea.

" Passerina anmua.

", Odontospermum aquaticum.

,, Euphorbia lanata.

" Ballota ruthestris. 
Annals of Botan:

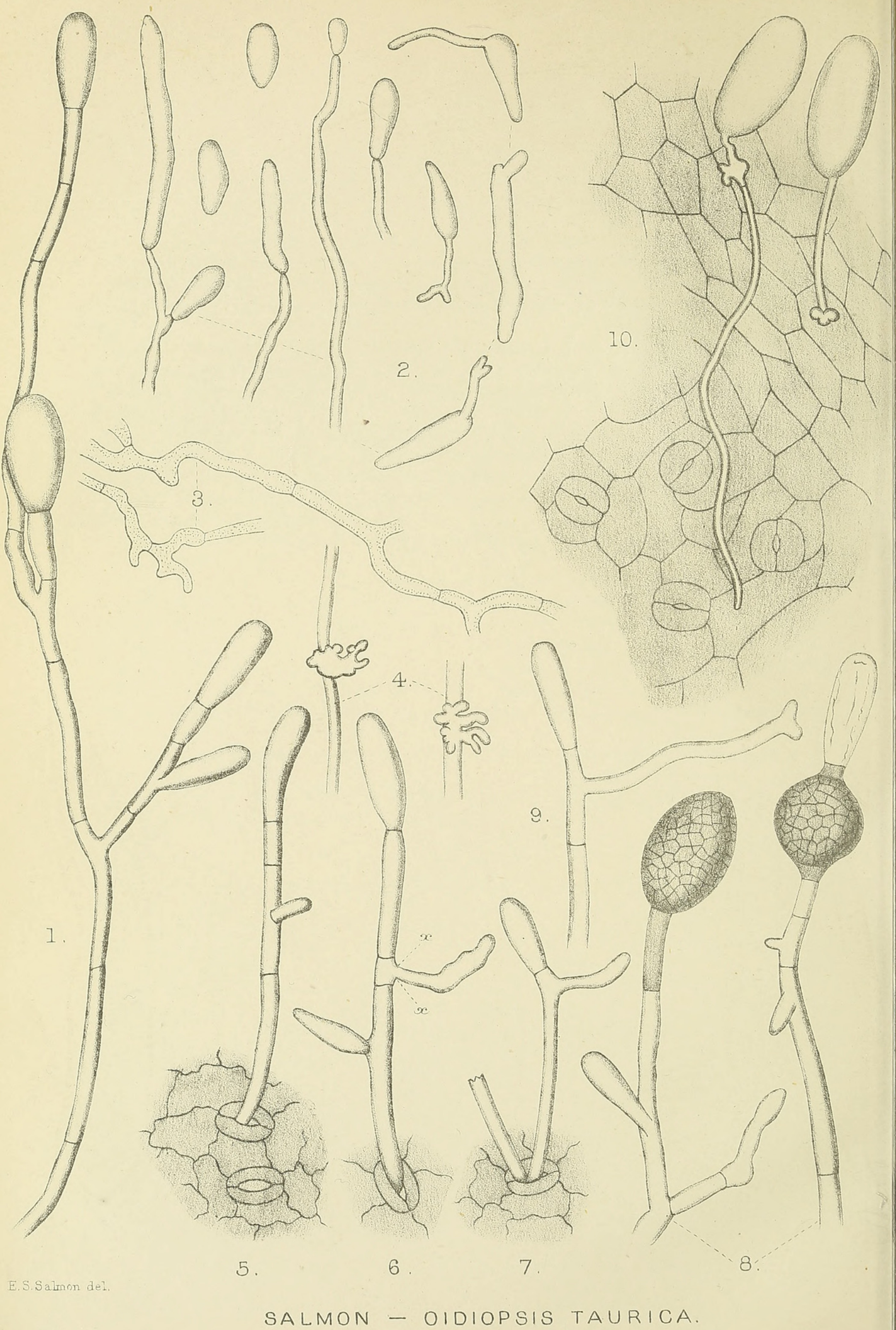


Vol. XX, Pl.XIII.

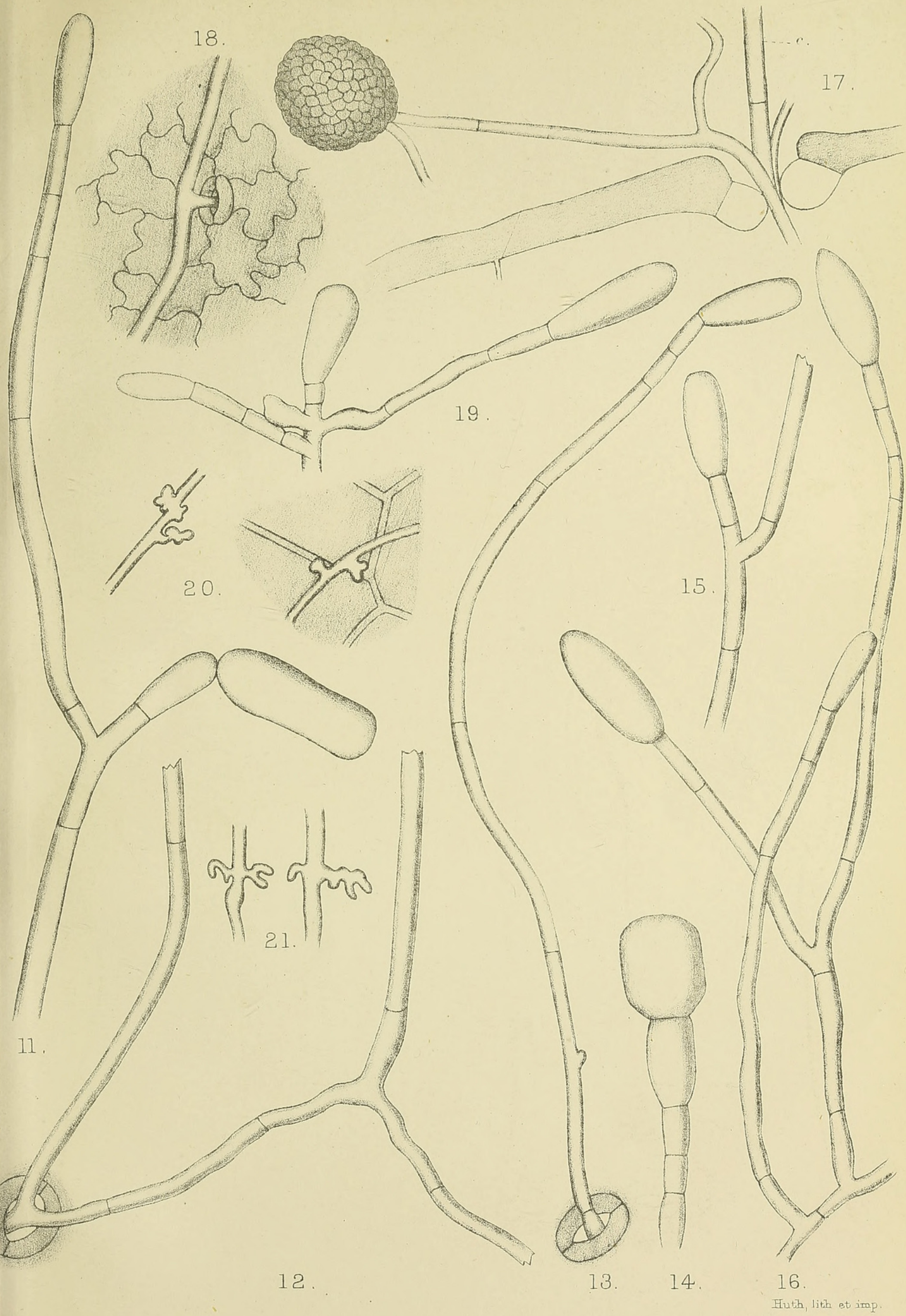




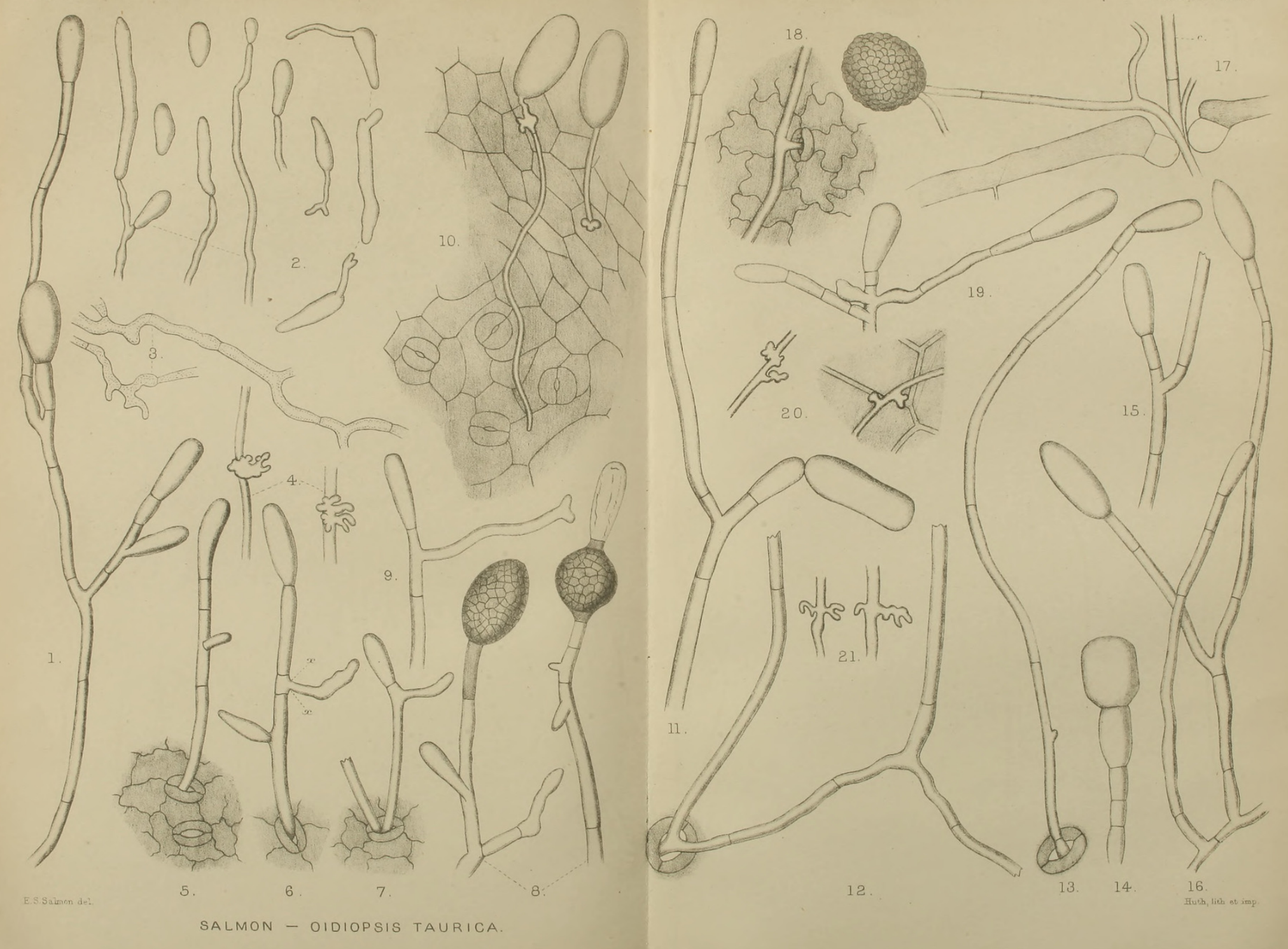


Annals of Botany

VoL XX, PL XII.

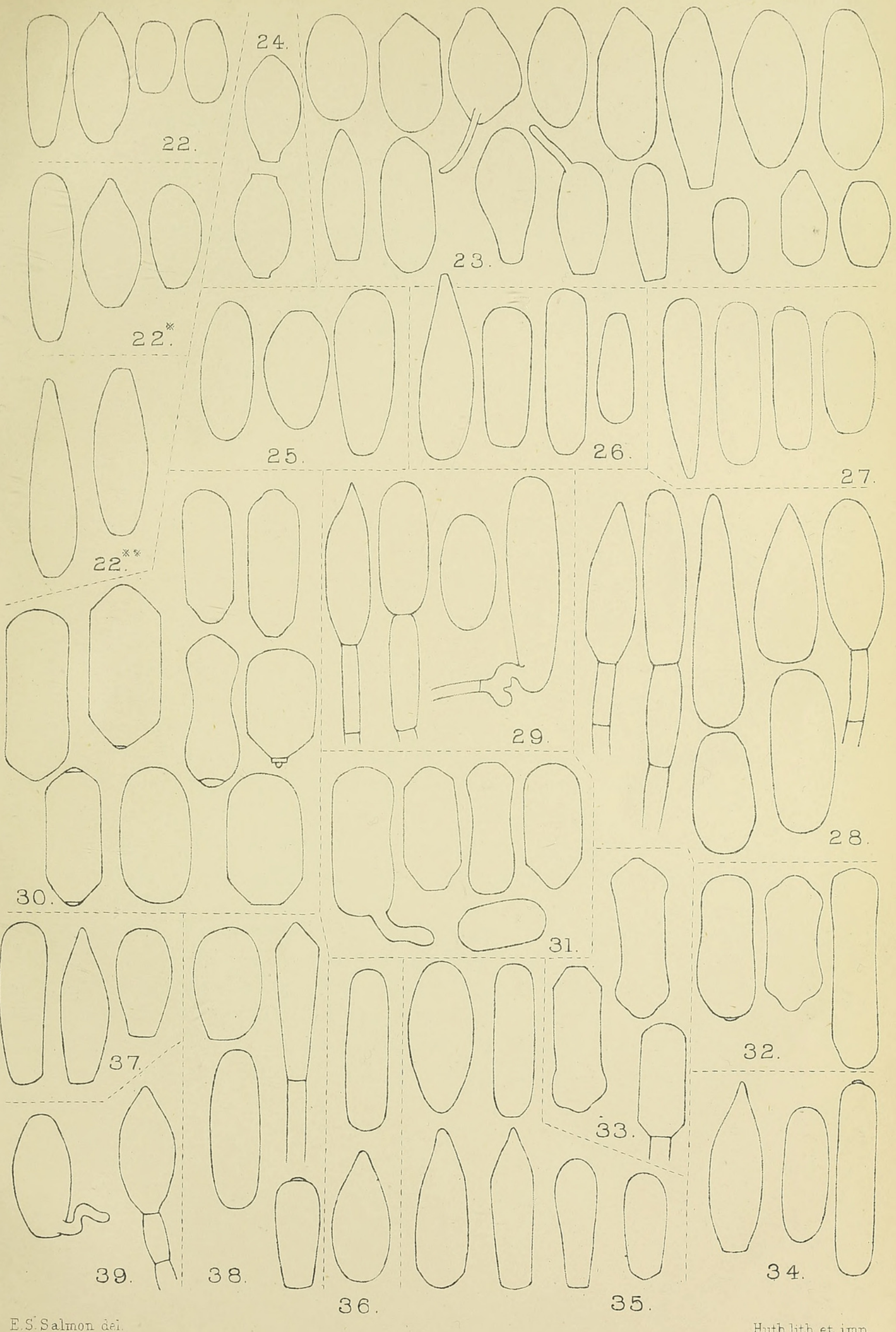

SALMON - OIDIOPSIS TAURICA. 


\section{$2 \mathrm{BHL}$ Biodiversity Heritage Library}

Salmon, Ernest Stanley. 1906. "On Oidiopsis taurica (Lév.), an endophytic member of the Erysiphaceae." Annals of botany 20, 187-200. https://doi.org/10.1093/oxfordjournals.aob.a089091.

View This Item Online: https://www.biodiversitylibrary.org/item/234848

DOI: https://doi.org/10.1093/oxfordjournals.aob.a089091

Permalink: https://www.biodiversitylibrary.org/partpdf/318831

\section{Holding Institution}

Smithsonian Libraries

\section{Sponsored by}

Biodiversity Heritage Library

\section{Copyright \& Reuse}

Copyright Status: Not in copyright. The BHL knows of no copyright restrictions on this item.

This document was created from content at the Biodiversity Heritage Library, the world's largest open access digital library for biodiversity literature and archives. Visit BHL at https://www.biodiversitylibrary.org. 